\title{
DAMPAK PENGGUNAAN TEKNOLOGI INFORMASI KOMUNIKASI TERHADAP POLA KOMUNIKASI MASYARAKAT DESA (Studi di Desa Melabun, Bangka Tengah, Kepulauan Bangka Belitung)
}

\author{
THE IMPACT OF USE OF INFORMATION COMMUNICATION \\ TECHNOLOGIES ON VILLAGERS COMMUNICATION PATTERNS \\ (A Case Study at Melabun Village, Central Bangka, Bangka Belitung Islands)
}

\author{
Christiany Juditha \\ Balai Pengembangan SDM dan Penelitian Komunikasi dan Informatika Manado \\ Kementerian Komunikasi dan Informatika RI \\ Jl. Pumorrow 76 Manado \\ christiany.juditha@kominfo.go.id
}

Diterima : 16 November 2019

Direvisi : 24 Januari 2020

Disetujui : 13 Juli 2020

\section{ABSTRACT}

The use of Information and Communication Technologies (ICTs) by rural communities from time to time has been increasing. This has led to changes in communication patterns of rural communities, both desirable and undesirable. Mediated communication through ICTs affects social relations and norms of rural communities, such as lessened direct communication and social participation. The purpose of this study was to comprehend the impact of the use of ICTs on the communication patterns of the people of Melabun Village, Central Bangka, Bangka Belitung. Using qualitative approach, the study concluded that most of the Melabun villagers have already used cellular phones to communicate, but only a few were connected to the internet due to infrastructure limitations. The use of ICTs in this village community had no significant effect on their direct communication patterns because apparently the villagers predominantly used direct/face-toface communication. However, mediated communication supported their daily activities, both in communicating and obtaining information.

Keywords: Information Communication Technology, communication patterns, rural communities

\begin{abstract}
ABSTRAK
Penggunaan Teknologi Informasi dan Komunikasi (TIK) oleh masyarakat desa dari waktu ke waktu semakin meningkat. Hal ini berdampak pada perubahan pola komunikasi masyarakat desa, baik secara positif maupun negatif. Komunikasi melalui TIK dapat memengaruhi hubungan dan norma-norma yang dianut masyarakat desa, di antaranya mengurangi komunikasi langsung serta partisipasi sosial. Tujuan penelitian ini adalah untuk mendapatkan gambaran tentang dampak penggunaan TIK terhadap pola komunikasi masyarakat Desa Melabun, Bangka Tengah, Bangka Belitung. Metode penelitian ini adalah studi kasus dengan pendekatan kualitatif. Hasil penelitian menyimpulkan bahwa masyarakat Desa Melabun sebagian besar sudah menggunakan telepon selular untuk berkomunikasi tetapi masih sedikit yang terhubung internet karena keterbatasan infrastruktur. Penggunaan TIK masyarakat desa ini juga tidak berpengaruh signifikan terhadap pola komunikasi mereka, karena masyarakat lebih banyak yang menggunakan komunikasi langsung/tatap muka. Namun komunikasi yang termediasi menjadi penunjang dalam aktivitas sehari-hari baik dalam berkomunikasi maupun dalam memperoleh informasi.
\end{abstract}

Kata Kunci: Teknologi Informasi Komunikasi, Pola Komunikasi, Masyarakat Desa 


\section{PENDAHULUAN}

Penggunaan komputer, laptop, telepon seluler dan internet sebagai bagian dari Teknologi Informasi dan Komunikasi (TIK) kini sudah digunakan baik oleh masyarakat di kota maupun di desa. Meski pertumbuhan penggunaannya tidak sama seperti di kota, penggunaan TIK di desa semakin meningkat. Kementerian Kominfo tahun 2017 pernah melakukan survei yang mengungkap bahwa kepemilihan telepon pintar atau smartphone dimiliki oleh $66,3 \%$ masyarakat Indonesia. Selain itu, individu yang bermukim di desa juga telah memiliki smartphone sebanyak $50,39 \%$, sementara sebanyak $32,30 \%$ di antaranya menggunakan internet untuk berkomunikasi (Kominfo, 2017). Tidak dipungkiri bahwa masyarakat yang tinggal di wilayah pedesaan tidak luput dari terpaan penggunaan TIK.

Fathoni (2010) mengatakan bahwa implementasi TIK di pedesaan bertujuan untuk meningkatkan kualitas hidup masyarakatnya. Hasil studi yang dilakukan oleh Newman, Davies-Slate dan Jones (2018) di India juga menyebutkan bahwa TIK berperan utama dalam pengembangan daerah perdesaan yang ramah lingkungan, pengembangan masyarakat perdesaan dan berkontribusi terhadap peningkatan perkembangan ekonomi dan sosial masyarakat di perdesaan India.

Penggunaan TIK ini juga berdampak pada perubahan pola komunikasi masyarakat secara umum di mana pun mereka tinggal. Respati mengatakan bahwa perkembangan TIK diikuti adanya perubahan gaya hidup masyarakatnya (Respati, 2014). Hadirnya TIK seperti media sosial dan instant messaging memungkinkan komunikasi antarmanusia secara lebih luas dan berlangsung secara realtime. Ruang-ruang interaksi baru untuk saling berkomunikasi secara virtual di antara masyarakat termediasi melalui media-media ini. Komunikasi konvensional (tatap muka) telah bermigrasi menjadi komunikasi virtual dengan cakupan audiens yang jauh lebih besar (Kominfo, 2017). Computer Mediated Communication atau CMC adalah jenis komunikasi yang diperantarai oleh internet yang tidak serta merta meniadakan komunikasi tatap muka. Thurlow et.al., mengatakan bahwa CMC mentransformasikan interaksi sosial yaitu identitas, hubungan, dan komunitas. Transformasi ini juga terjadi sebagai dampak dari akselerasi adopsi internet yang begitu cepat dibandingkan dengan media lainnya (Thurlow, 2004). Menurut Papsdorf (2015) internet tidak saja memfasilitasi intermediasi komunikasi sosial yang sebelumnya terjadi secara tatap muka. Akan tetapi, internet juga melakukan digitalisasi serta mentransmisikan secara teknis komunikasi yang sebelumnya telah termediasi.

Masyarakat desa merupakan institusi sosial yang masih dipengaruhi oleh normanorma, nilai, sistem sosial, serta budaya. Selama ini masyarakat desa masih mengandalkan cara berkomunikasi langsung karena dapat memengaruhi kualitas hubungan dan dianggap lebih sopan. Adanya TIK dalam berkomunikasi tidak saja memengaruhi hubungan tetapi juga memengaruhi norma dan nilai yang dianut masyarakat desa. Kraut et al., (1998) mengatakan komunikasi dengan orang lain, termasuk mengurangi partisipasi sosial di lingkungan sosial dapat terjadi karena tingginya penggunaan internet.

Desa Melabun yang menjadi objek penelitian ini merupakan pecahan dari Desa Sarangmandi, Melabun diresmikan menjadi desa pada tahun 2012. Sebelumnya, Melabun merupakan dusun tertua yang berada di 
Kecamatan Sungai Selan. Keberadaannya ini ditunjukkan dengan adanya pemukiman rumah penduduk yang masih bertahan sejak zaman penjajahan Portugis serta peta tentang Dusun Melabun yang telah terbentuk sejak tahun 1823 juga ditemukan. Meski menjadi desa tertua dan masih memegang adat istiadat setempat yang kuat, masyarakat Desa Melabun telah menggunakan TIK dalam aktivitas kehidupan mereka sehari-hari. Bagaimana penggunaan TIK tersebut berdampak pada pola komunikasi yang sudah lama ada di desa ini, itulah yang menarik untuk diteliti (Melabun, 2016).

Tidak dipungkiri bahwa penggunaan TIK seperti pedang bermata dua. Manfaat positif berada di satu sisi, sementara dampak negatifnya berada di sisi lainnya. Manfaat positif TIK dapat mengembangkan dan memberdayakan masyarakat desa untuk lebih maju. Sebaliknya, TIK juga dapat mengubah perilaku masyarakat desa ke arah negatif. Hal ini dimungkinkan mengingat salah satu ciri khas masyarakat tradisional adalah kurang kritis terhadap hal baru (Sinaga, 1988). Padahal, adat-istiadat serta kebiasaan yang telah dilakukan turun-temurun masih mengikat mereka.

Rumusan masalah penelitian ini yang disusun berdasarkan latar belakang adalah bagaimana dampak penggunaan teknologi informasi dan komunikasi terhadap pola komunikasi masyarakat Desa Melabun, Bangka Tengah, Bangka Belitung? Sedangkan untuk mendapatkan gambaran tentang dampak penggunaan teknologi informasi dan komunikasi terhadap pola komunikasi masyarakat Desa Melabun, Bangka Tengah, Bangka Belitung adalah tujuan dari penelitian ini.
Penelitian tentang pengaruh penggunaan teknologi informasi dan komunikasi (TIK) pada pola komunikasi masyarakat pernah dilakukan oleh Adventura dengan judul "Penggunaan Media Sosial dan Perubahan Pola Komunikasi Tatap Muka Masyarakat di Kompleks Dirgantara." Penelitian ini bertujuan untuk menggambarkan tentang warga kompleks dirgantara yang menggunakan media sosial dan juga perubahan pola komunikasi langsung atau tatap muka yang terjadi. Penelitian yang menggunakan metode kualitatif ini menyimpulkan bahwa baik penduduk asli maupun pendatang dalam komplek perumahan ini mengalami perubahan dalam pola komunikasi langsung atau komunikasi secara tatap muka. Komunikasi tatap muka warga berjalan secara interaktif, ketika belum banyak warga yang menggunakan media sosial. Namun, ketika masyarakat mulai banyak menggunakan media sosial, pola komunikasi juga ikut berubah. Selain itu, komunikasi secara langsung juga mulai jarang dilakukan oleh masyarakat karena menemui beberapa hambatan di antaranya karena warga yang cukup sibuk, komunikasi secara langsung terbatas karena waktu dan kesempatan yang juga sempit, dan juga sikap individualis massyarakat itu sendiri (Adventura, 2015).

Penelitian lain yang serupa dilakukan oleh Muljono et.al. dengan judul "Technological Determinism in Patterns of Communication and Social Behavior Change in Indonesian Society”. Studi ini membahas soal penetrasi teknologi komunikasi dalam komunikasi dan perilaku sosial pola masyarakat perdesaan dan perkotaan. Dengan menggunakan metode survei, penelitian ini menyimpulkan bahwa internet tidak memengaruhi sikap prososial dalam 
masyarakat tradisional, moderat, dan modern di komunitas perkotaan dan perdesaan. Selain itu, komunikasi tatap muka masih diandalkan saat berkomunikasi dengan keluarga. Teknologi komunikasi membantu proses komunikasi di luar keluarga, seperti dengan tetangga atau teman. Penelitian tersebut juga menyimpulkan bahwa media sosial kurang mendorong masyarakat berfungsi penuh (Muljono, Setiyawati dan Haryanto, 2017).

Puslitbang Aptika dan IKP Kementerian Komunikasi dan Informatika juga pernah melakukan penelitian tentang topik yang senada berjudul "Pola Komunikasi dan Perilaku Sosial Masyarakat Kota dan Desa di Era Teknologi Komunikasi”. Survei ini dilatarbelakangi oleh penetrasi internet yang semakin meningkat. Internet juga dinilai telah membawa perubahan drastis terhadap pola komunikasi dan interaksi manusia. Selain itu, dominasi komunikasi yang termediasi oleh komputer (internet) atau lebih dikenal dengan istilah Computer Mediated Communication memiliki dampak yang signifikan dalam komunikasi secara langsung atau tatap muka. Tujuan penelitian dengan metode survei ini adalah untuk mengeksplorasi dampak komunikasi yang diperantarai oleh teknologi komunikasi di tiga kelompok masyarakat, yakni tradisional, moderat dan modern terhadap perubahan komunikasi langsung atau tatap muka. Hasil penelitian menemukan bahwa komunikasi tatap muka masih tetap diandalkan ketika berkomunikasi di dalam lingkungan sosial yang kecil seperti keluarga. Sementara di lingkungan sosial yang semakin besar ada kecenderungan komunikasi tatap muka semakin jarang dilakukan. Teknologi komunikasi telah digunakan di dalam lingkungan keluarga, tetapi durasi penggunaannya masih tergolong rendah. Ada kecenderungan bahwa teknologi komunikasi menggantikan komunikasi interpersonal untuk lingkungan sosial di luar keluarga seperti tetangga. Selain itu, penetrasi teknologi komunikasi tidak serta merta mengubah tipe komunikasi keluarga. Orang tua cenderung lebih protektif dan anak patuh terhadap orang tua (Kominfo, 2017).

Penelitian-penelitan yang telah dipaparkan sebelumnya merupakan penelitian tentang pola komunikasi di kota dan di desa dan kota dengan metode penelitian survei kuantitatif. Penelitian ini tidak sama dengan penelitian-penelitian sebelumnya karena menggunakan pendekatan kualitatif dan objek penelitiannya juga adalah sebuah desa. Pendekatan kualitatif dipilih untuk lebih mengerti tentang cara individu atau komunitas dalam menerima isu tertentu (McCusker dan Gunaydin, 2015), dalam hal ini penggunaan TIK. Dengan pendekatan kualitatif, hasil penelitian dapat lebih dalam digali. Studi pun dilakukan secara lebih mendalam dengan mewawancarai para informan di desa tentang dampak penggunaan TIK di desa tersebut. Inilah yang membedakan penelitian ini dengan studi sebelumnya sehingga penting untuk dilakukan.

Perilaku manusia dengan menggunakan teknologi bertujuan untuk menyelesaikan berbagai tugas. Triandis menyatakan dalam teori sikap dan perilaku bahwa afeksi pengguna yang memengaruhi mereka dalam menggunakan personal computer (PC). Selain itu hal lain yang memengaruhi adalah konsekuensi individual yang diharapkan dari pemanfaatan PC, kondisi fasilitas dalam penggunaan $\mathrm{PC}$, norma sosial di tempat kerja serta kebiasaan pemanfaatan komputer (Triandis, 1980). 
Kini kehidupan masyarakat telah dirambah dengan perkembangan TIK. Hasil penelitian Kominfo menyebutkan bahwa penetrasi penggunaan perangkat TIK terkoneksi internet untuk berkomunikasi oleh masyarakat sangat tinggi, yakni mencapai $84,3 \%$. TIK merupakan faktor pendorong berbagai sektor, seperti di pemerintahan dan di perdesaan. Di daerah perdesaan, peningkatan kualitas hidup masyarakatnya secara signifikan dipengaruhi oleh penggunaan TIK. Kegagalan pembangunan tidak dapat diperbaiki oleh TIK, namun pembangunan akan berhasil baik dengan TIK (Kominfo, 2018). Seperti terungkap dalam hasil penelitian Badri yang menyebutkan bahwa jejaring dan pemberdayaan komunitas desa dapat dibangun oleh desa-desa inovatif. Gunanya agar kesenjangan TIK dapat dipersempit. Di samping itu, TIK juga mendorong aktivitas dan produktivitas masyarakat atau pemberdayaan (Badri, 2016).

Merespon fenomena komunikasi antarpribadi yang dimediasi oleh internet, O'Sullivan (2005) memberi usulan tentang konsep komunikasi masspersonal. Menurut Sullivan, media sosial maupun aplikasi instant messaging melalui jaringan internet dapat digunakan oleh seseorang untuk menyampaikan pesan-pesan interpersonal kepada seluruh jaringannya. Komunikasi yang bersifat interaksional semakin signifikan dengan hadirnya komunikasi masspersonal. Komunikasi tatap muka dan bersifat interaksional hanya terjadi secara konvensional. Dalam proses interaktif, dampak serta efektifnya proses pertukaran informasi yang terjadi menjadi tanggung jawab bersama pengirim dan penerima pesan. Hal ini menjadi titik berat dalam komunikasi transaksional. Selain itu, setiap aktor yang terlibat juga memiliki kesadaran bahwa ada saling ketergantungan antar komponen dalam komunikasi, makna terbangun serta satu sama lainnya ikut dan saling memengaruhi (West, 2010).

Model komunikasi ini berlaku juga dalam konteks komunikasi yang termediasi oleh teknologi. Foulger berpendapat bahwa model komunikasi transaksional melibatkan pembuat serta penerima pesan sebagai komunikator dan partisipan. Hanya pada komunikasi tatap muka atau komunikasi langsung yang memungkinkan model komunikasi ini dapat terjadi. Produksi dan konsumsi pesan dimungkinkan terjadi secara simultan pada medium interaktif. Dengan didukung teknologi web 2.0, internet memfasilitasi interaksi meski proses komunikasi yang terjadi bersifat asynchronous atau tidak terikat waktu (Foulger, 2004).

\section{Computer Mediated Communication} (CMC) atau komunikasi yang diperantarai oleh komputer berkembang karena penggunaan teknologi seperti sekarang ini. CMC sendiri adalah proses komunikasi dengan bantuan komputer di mana pengirim membuat pesan yang disampaikan kepada penerima (Liliweri, 2015). Komputer difungsikan sebagai media penyampai pesan dari satu orang ke orang lainnya.

TIK juga telah mengubah pola dan cara berkomunikasi masyarakat. Melalui TIK yang terhubung internet, terjadi desentralisasi seluruh pesan komunikasi, pesan didistribusikan secara meningkat, begitu pula dengan audiens dalam proses komunikasi ikut terlibat. Komunikasi yang terjadi bersifat dua arah dan memungkinkan terjadinya interaksi antara komunikator dan komunikan (McQuail, 2011). Hal ini juga memengaruhi pola komunikasi langsung (tatap muka) yang kini 
semakin berkurang dilakukan karena penggunaan TIK dalam berkomunikasi.

Djamarah (2004) mengatakan bahwa pola komunikasi adalah pemahaman yang baik atas pesan yang disampaikan dari pengirim ke penerima. Proses komunikasi ini terjadi antara dua orang atau lebih dalam sebuah pola hubungan. Sementara Gunawan (2013) mengatakan bahwa untuk mencapai kemudahan pemikiran yang sistematik dan logis, maka dirancanglah sebuah pola komunikasi. Tujuannya untuk menyatukan berbagai unsur yang dicakup beserta keberlangsungannya. Soejanto mengatakan bahwa pola komunikasi dapat digambarkan secara sederhana yaitu satu komponen komunikasi dengan komponen lainnya saling terkait satu sama lainnya dalam sebuah proses komunikasi (Santi, Koagouw dan Mingkid, 2015).

Dalam proses komunikasi, terdapat pola komunikasi yaitu aktivitas pesan yang disampaikan kepada penerima pesan yang kemudian menghasilkan umpan balik. Ada beberapa jenis pola komunikasi, yakni: 1) Pola komunikasi primer, yaitu suatu simbol digunakan sebagai saluran atau media dalam suatu proses penyampaian pesan dari komunikator ke komunikan; 2) Pola komunikasi sekunder, yakni alat atau sarana digunakan sebagai media dalam proses pesan disampaikan dari komunikator kepada komunikan; 3) Pola komunikasi linier, yakni suatu proses penyampaian pesan secara langsung atau linier yang dilakukan secara tatap muka oleh komunikator kepada komunikan; 4) Pola komunikasi sirkular, yakni suatu proses penyampaian pesan dari komunikator kepada komunikan yang berlangsung secara terus menerus disebabkan oleh adanya feedback atau umpan balik diantara mereka (Effendi, 2008). Masyarakat di perdesaan cenderung melakukan komunikasi antarpersonal yaitu informasi dipertukarkan antara minimal dua orang atau lebih yang umpan baliknya dapat langsung diketahui (Firdaus, 2016). Hal ini masuk kategori pola komunikasi yang linier/langsung.

Penelitian ini menyasar masyarakat desa sebagai subjek penelitian. Masyarakat secara umum didefinisikan sebagai sekumpulan manusia yang saling bergaul dan berinteraksi (Koentjaraningrat, 2009). Adapun menurut Setiadi (2013), masyarakat memiliki kehidupan yang selalu dinamis dan berubah. Hal ini tidak dapat dihindari. Namun masyarakat dalam sebuah kelompok selalu terhubung satu dengan lainnya dan juga saling berinteraksi.

Masyarakat perdesaan sifatnya gradual (Soekanto, 2006). Lebih lanjut, Soekanto menyatakan masyarakat desa umumnya hidup bertani. Sebuah hubungan yang lebih erat dan mendalam biasanya dimiliki oleh masyarakat desa. Sistem kehidupannya pun juga terbentuk secara kelompok dengan dasar kekeluargaan. Ciri-ciri masyarakat antara lain berinteraksi, semua aspek kehidupan yang bersifat mantap dan kontinyu terjadi dalam sebuah ikatan pola tingkah laku yang khas. Selain itu, masyarakat desa juga memiliki rasa identitas terhadap kelompok, yang anggotanya terdiri dari individu-individu. Sebagian besar masyarakat desa merupakan masyarakat tradisional. Vatsayan dalam Ramakrishnan menyatakan bahwa masyarakat tradisional sering disebut sebagai masyarakat adat atau suku, biasanya mengumpulkan pengetahuan lingkungan yang signifikan melalui pengalaman sehari-hari mereka dengan alam dan sumber daya alam (Ramakrishnan, 2001). Adapun Amiruddin (2010) menyebutkan solidaritas sosial mekanis 
yang muncul karena adanya konsensus, kesamaan, dan pertukaran informasi antara satu individu dengan individu yang lain adalah kecenderungan yang dimiliki oleh masyarakat tradisional.

Berdasarkan kerangka teori dan konsep yang telah dipaparkan sebelumnya, maka kerangka pemikiran dari penelitian ini merepresentasikan tentang dampak penggunaan TIK (telepon seluler dan internet) terhadap pola komunikasi masyarakat Desa Melabun. Adapun kerangka konseptual dari penelitian ini dapat digambarkan dalam Gambar 1 sebagai berikut:

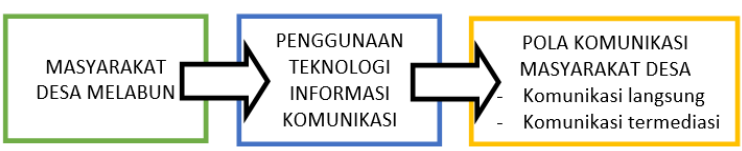

Gambar 1. Kerangka Konseptual

\section{METODOLOGI PENELITIAN}

Penelitian ini menggunakan pendekatan kualitatif dengan metode studi kasus. Yin (2015) menjelaskan bahwa "studi kasus merupakan strategi penelitian yang menyelidiki secara cermat suatu program, peristiwa, aktivitas, proses, atau sekelompok individu. Kasus-kasus dibatasi oleh waktu dan aktivitas dan peneliti mengumpulkan informasi secara lengkap dengan menggunakan berbagai prosedur pengumpulan data dengan batas waktu yang telah ditentukan". Adapun pendekatan kualitatif menurut Bogdan dan Taylor dalam Moleong (2012) adalah dari orang-orang dan perilaku yang dapat diamati kemudian menghasilkan data deskriptif berupa kata-kata tertulis atau lisan.

Lokasi penelitian adalah Desa Melabun, Kecamatan Bangka Tengah, Kabupaten Bangka Belitung. Alasan pemilihan Desa Melabun disebabkan desa ini merupakan dusun tertua di Kecamatan Sungai Selan dan masih memegang kuat adat istiadat setempat dalam aktivitas kehidupan sehari-hari (Melabun, 2016).

Teknik pengumpulan data dalam penelitian ini terdiri dari dua jenis. Pertama, data primer yang diperoleh langsung dari sumber utama atau informan inti. Caranya dengan mendatangi lokasi penelitian dan melakukan wawancara langsung (Sutrisno, 2001). Para informan di desa yang diwawancarai adalah tokoh agama, kepala desa/tokoh masyarakat, kepala sekolah/guru komputer, pemuda karang taruna, ketua komunitas/kelompok tani, serta pakar komunikasi dan TIK. Adapun nama-nama informan yaitu Darsono, Syaril, Anthoni, dan Sapar. Kedua, data sekunder. Data sekunder menurut Sugiyono adalah sumber data yang tidak langsung memberikan data kepada pengumpul data, misalnya melalui orang lain atau lewat dokumen. Dokumen tersebut yang hubungan dengan penelitian yang sedang dilakukan, mencakup artikel, literatur, situs di internet, serta jurnal (Sugiyono, 2013).

Data yang diperoleh melalui wawancara, observasi dan kajian pustaka ini kemudian diolah berdasarkan kebutuhan penelitian sebagai metode atau cara menganalisis data. Teknik analisis data penelitian ini adalah. Analisis data dilakukan dengan memberi kode terhadap hasil wawancara atau menyusunnya sesuai kebutuhan penelitian. Hasil coding ini kemudian dianalisis untuk menjawab rumusan masalah secara deskriptif.

Moleong (2012) menjelaskan teknik triangulasi merupakan teknik keabsahan data dalam sebuah penelitian. Teknik ini untuk mengecek serta memeriksa keabsahan data yang telah ada yang kemudian dibandingkan dengan data lain. Penelitian ini menggunakan 
triangulasi data baik dengan mengkomparasi hasil penelitian sebelumnya, juga mengecek secara teori, konsep untuk meneliti keabsahan data serta memperkaya hasil analisis. Perbandingan informasi atau data dengan cara yang berbeda, atau penggunaan lebih dari satu orang dalam proses pengumpulan dan analisis data adalah cara melakukan triangulasi. Selain itu menggali kebenaran informasi tertentu melalui berbagai metode dan sumber juga dilakukan. Kemudian agar terhindar dari bias individual peneliti atas hasil penelitian yang ditemukan, maka seluruh informasi yang diperoleh juga dibanding dengan perspektif teori yang relevan.

\section{HASIL DAN PEMBAHASAN}

Desa Melabun terletak di Kecamatan Sungai Selan, Kabupaten Bangka Tengah, Provinsi Kepulauan Bangka Belitung. Melabun merupkan desa hasil pemekaran yang sebelumnya bergabung di Desa Sarangmandi. Tepat tanggal 10 Februari 2012, Melabun diresmikan menjadi sebuah desa. Melabun dulunya juga dikenal sebagai sebuah dusun tertua di Kecamatan Sungai Selan. Ini karena di desa ini, masih tersisa pemukiman rumah penduduk yang telah berdiri sejak tahun 1819 di zaman penjajahan bangsa Portugis. Hal ini diperkuat dengan temuan peta dusun Melabun yang dibuat pada tahun 1823. Nama Melabun sendiri diambil dari nama kayu yang biasa digunakan warga setempat untuk menangkap ikan. Desa Melabun dikenal banyak memiliki lubuk yang banyak ikannya (Melabun, 2016b).

Meski termasuk desa tertua dan masih kental menganut adat istiadat dan agama, masyarakat desa ini tidak dapat menghindari kemajuan serta penggunaan TIK. Di sektor pendidikan misalnya, sebagaimana dinyatakan oleh Syahril yang merupakan guru Sekolah
Negeri Desa Melabun bahwa kebanyakan pengajar atau guru di sekolah tempatnya mengabdi sudah menggunakan TIK seperti telepon seluler, komputer/laptop dan internet. Begitu juga dengan pekerjaan yang berhubungan dengan administrasi di sekolah. Syahril juga mengatakan bahwa di sekolah belum ada jaringan internet sehingga mereka kebanyakan mencarinya di luar sekolah.

Di sektor pertanian, Antoni, salah seorang anggota komunitas tani Desa Melabun, juga mengatakan bahwa para anggota kelompok tani sudah menggunakan TIK seperti telepon seluler. Kalaupun ada anggota yang belum menggunakannya, hal itu dikarenakan kurangnya keterampilan yang dimiliki.

Sementara untuk pergaulan sosial seharihari, masyarakat desa secara umum telah memanfaatkan perangkat TIK yang paling sederhana seperti HP. Hal ini terlihat dari penuturan Kepala Desa Melabun, Darsono, berikut ini.

"Secara keseluruhan, per rumah sudah menggunakan. Tapi yang tidak mau pakai itu karena tidak mau pakai, misalnya karena sudah berumur dan tidak tahu bagaimana caranya memakai." (Wawancara Kepala Desa Melabun, Darsono).

Keberadaan TIK, dalam hal ini telepon seluler, sebagai media komunikasi tentu memengaruhi cara berkomunikasi masyarakat Desa Melabun. Namun ketika ditanyakan kepada para informan tentang komunikasi yang paling dominan di desa tersebut, semua informan sepakat bahwa komunikasi tatap muka atau komunikasi secara langsung kerap mendominasi dibanding komunikasi melalui media. Sekalipun demikian, komunikasi yang termediasi menjadi penunjang dalam aktivitas 
masyarakat sehari-hari. Seperti disampaikan oleh Syaril bahwa TIK memengaruhi cara mereka berkomunikasi, khususnya di lingkungan sekolah. Meski jaringan internet belum terlalu baik, sekolah sudah memiliki grup-grup instant messaging di WhatsApp untuk mempermudah komunikasi

"Kami biasanya kalau kepala sekolah
memiliki grup WA sekecamatan. Dan
dari situ proses informasi disebarkan.
Tetapi kalau antarguru belum ada,
kita hanya menyimpan nomor teman,
sehingga pada saat ada informasi
penting, kita langsung menghubungi
yang bersangkutan melalui HP.
Begitu pun kalau ada masalah-
masalah tertentu, apa solusinya dan
lain sebagainya." (Wawancara Guru
Desa Melabun, Syahril).

Ketua Kelompok Tani Desa Melabun, Antoni juga menyampaikan hal senada. Menurut Antoni, di Desa Melabun terdapat lima Kelompok Tani (Poktan) yang terdiri dari beberapa kepala keluarga $(\mathrm{KK})$, semisal 20 KK. Kelompok tani ini biasa membagikan informasi tentang pertanian secara langsung (komunikasi langsung) saat mereka melakukan pertemuan rutin.

Begitu juga yang disampaikan oleh Sapar, anggota pemuda Karang Taruna Desa dan Kepala Desa Melabun, Darsono. Keduanya sepakat bahwa di desa mereka komunikasi langsung masih dominan dilakukan oleh masyarakat:

"Masih tatap muka/komunikasi langsung, karena jangkauan di desa masih terbilang dekat-dekat. Jika menggunakan TIK seperti HP hanya untuk berkomunikasi untuk hal-hal yang penting dan mendesak." (Wawancara Anggota Karang Taruna Desa Melabun, Sapar).
Penggunaan TIK memberikan dampak yang cukup baik terhadap pola komunikasi masyarakat Desa Melabun. Seperti diakui oleh Darsono bahwa dengan menggunakan perangkat TIK seperti handphone, komunikasi bisa lebih efektif dan cepat. Begitu juga dengan pemanfaatan komputer, pekerjaan seperti administrasi di kantor desa menjadi lebih baik. Meski demikian, Darsono mengakui penggunaan TIK tidak langsung memengaruhi nilai-nilai yang dianut oleh masyarakat Desa Melabun ysng masih tetap dipertahankan. Bagi mereka, komunikasi secara langsung dalam menyampaikan hal-hal tertentu, semisal dalam acara keluarga, terasa masih lebih sopan jika tidak disampaikan melalui media.

Hal senada juga diungkapkan oleh Ketua Kelompok Tani Desa Melabun, Antoni. Menurutnya, dengan adanya smartphone, mereka dapat memperoleh informasi seperti media tanam, harga pupuk, dan lain-lain. Hal tersebut sangat bermanfaat untuk dibagikan kepada para anggota Poktan lainnya. Hanya saja, jaringan internet di Desa Melabun masih sangat terbatas sehingga informasi yang diperoleh juga masih sangat terbatas. Salah satunya adalah belum adanya informasi tentang cara mengomunikasikan produk secara online.

Begitu juga yang disampaikan oleh Sapar. Menurutnya, belum dibentuknya grupgrup di media sosial karena dianggap belum terlalu penting. Apalagi tempat tinggal anggota masyarakat juga dekat. Jadi, komunikasi tatap muka atau komunikasi langsung masih sering digunakan. TIK seperti HP hanya dipakai untuk mengomunikasikan hal-hal yang penting dan mendesak. Sapar juga mengatakan bahwa pemuda di Desa Melabun rata-rata hanya berprofesi sebagai petani sehingga pola pikir 
mereka hanya sebatas agar kebutuhan seharihari dapat terpenuhi. Oleh karena itu, pengembangan usaha melalui pemasaran online dengan menggunakan TIK belum terlalu mereka pikirkan.

Hingga di sini dapat disimpulkan bahwa komunikasi yang paling dominan di desa Melabun masih tetap komunikasi langsung atau tatap muka. Hal ini termasuk pola komunikasi linier yaitu pesan yang disampaikan dari komunikator kepada komunikan berlangsung secara langsung/linier atau tatap muka tanpa perantaraan media (Effendi, 2008). Masyarakat perdesaan cenderung melakukan komunikasi antarpersonal, yaitu pertukaran informasi antara minimal dua orang yang dapat langsung diketahui umpan baliknya (Firdaus, 2016).

Meski demikian, komunikasi yang termediasi menjadi penunjang dalam aktivitas masyarakat sehari-hari, baik untuk berkomunikasi maupun bekerja. Kelompokkelompok tani di desa ini misalnya, telah biasa membagikan informasi pertanian secara langsung. Namun, dengan adanya telepon seluler sangat membantu para petani dalam memperoleh informasi seperti media tanam, harga pupuk, dan lain-lain secara lebih cepat dari anggota kelompok lainnya. Hal ini sejalan dengan hasil penelitian yang dilakukan oleh Campbell dan Kwak yang menyebutkan bahwa komunikasi melalui telepon seluler membantu untuk mendapatkan informasi dan juga dan bertukar informasi (Campbell dan Kwak, 2011).

Penggunaan TIK memberikan dampak yang cukup baik terhadap pola komunikasi masyarakat Desa Melabun. Dengan menggunakan perangkat TIK seperti telepon seluler, komunikasi bisa berjalan lebih efektif dan lebih cepat. Begitu juga dengan pemanfaatan komputer yang membuat pekerjaan administratif di kantor desa menjadi lebih baik. Meski demikian, masyarakat Desa Melabun masih tetap mempertahankan komunikasi secara langsung dalam menyampaikan hal-hal tertentu, misalnya dalam acara keluarga. Hal ini dianggap masih lebih sopan jika disampaikan tidak melalui media. Hasil ini juga sejalan dengan hasil penelitian yang dilakukan oleh Misra et.al. yang menyebutkan bahwa komunikasi tanpa teknologi komunikasi seluler dinilai jauh lebih unggul dibandingkan dengan komunikasi bermedia. Penelitian ini menyebutkan bahwa orang yang melakukan komunikasi secara langsung atau tidak melalui perangkat seluler memiliki tingkat kepedulian empati yang lebih tinggi. Sebaliknya, mereka yang berkomunikasi dengan menggunakan media selular, tingkat empatinya lebih rendah (Misra et al., 2016).

Perkembangan teknologi komunikasi dalam sejarahnya selalu diiringi dengan perubahan sosial, termasuk perubahan pola komunikasi dalam masyarakat (Bala, 2014). Telegraf dan telepon misalnya, ketika pertama kali ditemukan pada abad ke 17 dan 18, mampu merevolusi sistem komunikasi manusia dari pertemuan tatap muka dan langsung, ke dalam bentuk media teks, simbol dan suara. Telegraf dan telepon mampu mengirimkan pesan lintas geografis. Sementara telepon seluler saat ditemukan pertengahan tahun 70-an, juga telah membuat komunikasi melalui media semakin tidak terbatas.

Thurlow (2004) mengungkapkan bahwa orang bisa menghubungi orang lain kapan saja dan dimana saja karena adanya teknologi komunikasi. Teknologi komunikasi, pada dasarnya, memiliki lintasan perkembangan 
yang sama, yaitu menuju teknologi yang menjangkau jarak yang lebih luas, membawa informasi lebih banyak dan lebih cepat, serta melibatkan banyak orang. Penggunaan internet pun demikian. Internet telah membawa perubahan drastis terhadap pola komunikasi dan interaksi manusia. Bila dulu informasi hanya disiarkan serempak dan bersifat satu arah, saat ini melalui internet dimungkinkan terjadinya kolaborasi dan interaksi antarindividu tanpa batasan ruang dan waktu serta melibatkan jaringan individu dengan jaringan individu lainnya.

Studi-studi sebelumnya mengungkapkan bahwa terjadi perubahan dalam individu maupun masyarakat secara keseluruhan karena pengaruh teknologi. Dan keduanya ini memiliki hubungan. Menurut Alvin Toffler dalam Preston (2001), perubahan sosial, ekonomi dan politik diakibatkan karena teknologi informasi dan komunikasi dan merupakan dampak revolusioner. Baek dan Morimoto (2012) menemukan bahwa media yang bersifat personal seperti telepon memiliki pengaruh terhadap perubahan sosial dibandingkan media massa seperti televisi. Adapun media yang sifatnya masspersonal seperti media jejaring sosial yang tidak memiliki batasan antara komunikator dan komunikan ataupun antara produsen dan konsumen informasi memiliki pengaruh terhadap perubahan sosial. Komunikasi yang dimediasi oleh komputer maupun internet yang dikenal dengan Computer Mediated Communication (CMC) juga memberikan dampak signifikan terhadap komunikasi tatap muka masyarakat. Ini pun terlihat dari hasil penelitian masyarakat di Desa Melabun, meski dampaknya tidak sebesar pada masyarakat yang tinggal di wilayah perkotaan.
Pola dan cara berkomunikasi masyarakat telah diubah oleh TIK. Hal ini memungkinkan terjadinya interaksi antara pengirim dan penerima pesan, diskusi, pengiriman berbagai jenis gambar, data suara dan teks yang merupakan konten dari media baru (McQuail, 2011), seperti yang dilakukan oleh masyarakat di Desa Melabun. Akan tetapi, komunikasi yang sifatnya konvensional atau komunikasi langsung tanpa dimediasi oleh media, masih menjadi hal yang utama dilakukan oleh masyarakat Desa Melabun. Temuan ini sejalan dengan paparan Sugiana (2016) yang menyebutkan bahwa masyarakat desa masih menganggap jaringan komunikasi sangat penting. Hal ini karena hubungan sosial berhadapan muka antara para pelakunya masih dapat terjadi, termasuk hubungan sosial yang mendalam dan berlaku kepada orang-orang meski berbeda status. Dalam masyarakat desa, pemberi pesan juga dinilai oleh si penerima pesan dari sisi identitasnya dan bukan dari isi pesannya. Jaringan komunikasi tradisional juga sudah lama berjalan, dan pola ini mampu menyebarkan berita antarwarga desa.

\section{KESIMPULAN DAN SARAN}

Kesimpulan dari penelitian ini adalah bahwa masyarakat di Desa Melabun umumnya sudah menggunakan TIK, khususnya telepon seluler dan kebanyakan hanya digunakan untuk berkomunikasi semata. Sementara penggunaan telepon seluler yang terhubung internet hanya digunakan oleh sebagian kecil masyarakat karena keterbatasan jaringan di desa tersebut. Laptop dan komputer sudah digunakan oleh aparat desa, guru, mahasiswa, serta pemuda Karang Taruna. Sementara masyarakat umum yang kebanyakan berprofesi sebagai petani dan peternak, belum banyak yang menggunakan perangkat-perangkat 
tersebut karena tidak memiliki sarana dan keterampilan.

Komunikasi yang paling dominan di desa Melabun masih tetap komunikasi langsung atau tatap muka. Bagi mereka, komunikasi secara langsung dalam menyampaikan informasi dalam konteks privat, semisal urusan keluarga, masih lebih sopan jika disampaikan tidak melalui media, meski hal tersebut bisa saja disampaikan dengan perantaraan media (telepon seluler). Dengan demikian, penggunaan TIK dalam berkomunikasi tidak mengubah pilihan masyarakat desa untuk tetap berkomunikasi secara langsung.

Meski hanya sedikit masyarakat desa yang menggunakan internet, namun hal tersebut cukup dirasakan manfaatnya. Masyarakat tani misalnya, dapat memperoleh informasi seperti media tanam, harga pupuk, dan lain-lain yang kemudian dapat dibagikan kepada anggota lainnya yang tidak memiliki akses internet. Hanya saja, jaringan internet di Desa Melabun masih sangat terbatas sehingga informasi yang diperoleh juga masih sangat terbatas. Hal ini menyebabkan ketiadaan informasi mengenai cara mengomunikasikan produk-produk kelompok tani melalui penjualan online. Desa ini juga belum memiliki komunitas yang memanfaatkan ecommerce untuk memasarkan hasil produknya. Di lingkungan sekolah, penggunaan TIK juga memengaruhi cara berkomunikasi. Meski jaringan internet belum terlalu baik, sekolah sudah memiliki grup-grup instant messaging di WhatsApp untuk mempermudah komunikasi

Penelitian ini merekomendasikan perlunya literasi penggunaan TIK pada masyarakat desa. Hal ini penting mengingat pengggunaan TIK tidak semata untuk berkomunikasi tetapi juga untuk meningkatkan kesejahteraan hidup masyarakat. Penggunaan TIK melalui grup-grup instant messaging juga dapat mempererat hubungan kekeluargaan meski tidak berlangsung secara fisik. Penggunaan TIK juga perlu dioptimalkan pada masyarakat desa agar hasil-hasil produksi desa seperti pertanian dan perikanan dapat dipromosikan atau dikomunikasikan melalui media digital agar taraf hidup masyarakat desa dapat lebih meningkat.

\section{UCAPAN TERIMA KASIH}

Terima kasih kepada pimpinan Puslitbang APTIKA dan IKP Kementerian Kominfo, yang telah menyediakan sarana prasarana, izin sekaligus dana untuk melakukan penelitian ini. Terima kasih juga kepada Kepala Desa Melabun, Kecamatan Sungai Selan, Bangka Tengah, Kepulauan Bangka Belitung, Bapak Darsono dalam memberikan informasi yang dibutuhkan selama penelitian berlangsung. Terima kasih juga saya haturkan kepada para informan, yakni Bapak Darsono, Syaril, Antoni, dan Sapar.

\section{DAFTAR PUSTAKA}

Adventura, E. N. (2015) Penggunaan Media Sosial Dan Perubahan Pola Komunikasi Tatap Muka Masyarakat Di Kompleks Dirgantara. Yogyakarta: UPN Veteran Yogjakarta.

Amiruddin (2010) Pengantar Metode Penelitian Hukum. Jakarta: PT Raja Grafindo Persada.

Badri, M. (2016). 'PEMBANGUNAN PEDESAAN BERBASIS TEKNOLOGI INFORMASI DAN KOMUNIKASI (Studi pada Gerakan Desa Membangun)', Jurnal Risalah, 27(2), pp. 62-73. doi: 10.24014/jdr.v27i2.2514. Baek, T. H. and Morimoto, M. (2012). 'Stay 
Away From Me', Journal of Advertising. Routledge, 41(1), pp. 59-76. doi: 10.2753/JOA0091-3367410105.

Bala, K. (2014). 'Social Media and Changing Communication Patterns', Global Media Journal: Indian Edition, 5(1), pp. 1-6. Available at: http://proxy.lib.csus.edu/login?url=http:// search.ebscohost.com/login.aspx?direct= true $\& \mathrm{db}=$ ufh $\& A \mathrm{AN}=98477971$.

Campbell, S. W. and Kwak, N. (2011). 'Mobile Communication and Civil Society: Linking Patterns and Places of Use to Engagement with Others in Public', Human Communication Research, 37(2), pp. 207-222. doi: 10.1111/j.1468-2958.2010.01399.x.

Djamarah, B. (2004). Pola Komunikasi Orang Tua \& Anak Dalam keluarga. Jakarta: PT. Reneka Cipta.

Effendi, O. U. (2008). Dinamika Komunikasi. Bandung: PT Remaja Rosdakarya.

Fathoni, A. (2010). Organisasi dan Manajemen Sumber Daya Manusia. Jakarta: Rineka Cipta.

Firdaus (2016). POLA KOMUNIKASI MASYARAKAT DESA DAN KOTA. Jakarta: Fikom Universitas Mercu Buana.

Foulger, D. (2004). An Ecological Model of the Communication Process.

Gunawan, I. (2013). Metode Penelitiaan Kualitatif: Teori dan Pratilik. Jakarta: Bumi Aksara.

Koentjaraningrat. (2009). Pengantar Ilmu Antropologi. Jakarta: Rineka Cipta.

Kominfo. (2017). Survey Penggunaan Teknologi Informasi dan Komunikasi (TIK) Sertra Implikasinya terhada Aspek Sosial Budaya Masyarakat. Jakarta.

Kominfo. (2018). Penggunaan TIK dan Implikasinya terhadap Aspek Sosial Budaya Masyarakat. Jakarta: Puslitbang APTIKA dan IKP Kementerian Kominfo.

Kraut, R. et al. (1998). 'Internet paradox: A social technology that reduces social involvement and psychological wellbeing?', American Psychologist, 53(9), pp. 1017-1031. doi: 10.1037/0003066X.53.9.1017.

Liliweri. (2015). Komunikasi Antar Personal. Jakarta: Kencana Prenadamedia.

McCusker, K. and Gunaydin, S. (2015). 'Research using qualitative, quantitative or mixed methods and choice based on the research', Perfusion, 30(7), pp. 537542. doi: 10.1177/0267659114559116.

McQuail, D. (2011). Teori Komunikasi Massa McQuail, Edisi 6 Buku 1. Jakarta: Salemba Humanika.

Melabun. (2016). Sejarah Desa Melabun. Available at: http://melabun.batengunggul.id/index.ph $\mathrm{p} /$ first/artikel/99.

Misra, S. et al. (2016). 'The iPhone Effect', Environment and Behavior, 48(2), pp. 275-298. doi: $10.1177 / 0013916514539755$.

Moleong. (2012). Metodologi Penelitian Kualitatif. Bandung: Bandung.

Muljono, W., Setiyawati, S. and Haryanto, B. (2017). 'Technological Determinism in Patterns of Communication and Social Behavior Change in Indonesian Society', Asian Social Science, 13(2), p. 21. doi: 10.5539/ass.v13n2p21.

Newman, P., Davies-Slate, S. and Jones, E. (2018). 'The Entrepreneur Rail Model: Funding urban rail through majority private investment in urban regeneration', Research in Transportation Economics. Elsevier Ltd, 67, pp. 19-28. doi: 10.1016/j.retrec.2017.04.005.

O’Sullivan, P. (2005). 'Masspersonal Communication: Rethinking the MassInterpersonal Divide', International Communication Association, pp. 1-34.

Papsdorf, C. (2015). 'How the Internet automates communication', Information, Communication \& Society. Routledge, 18(9), pp. 991-1005. doi: 10.1080/1369118X.2015.1008539. 
Preston, P. (2001). Reshaping Communications: Technology, Information and Social Change. London, Thousand Oaks, New Delhi: SAGE Publications, Inc.

Ramakrishnan, P. (2001). Ethnobiology. International Encyclopedia of the Social \& Behavioral Sciences.

Respati, W. (2014). 'Transformasi Media Massa Menuju Era Masyarakat Informasi di Indonesia', Humaniora, $5(1), \quad$ p. $39 . \quad$ doi: 10.21512/humaniora.v5i1.2979.

Santi, M. R., Koagouw, F. and Mingkid, E. (2015). 'Pola komunikasi anak-anak delinkuen pada keluarga broken home di Kelurahan Karombasan Selatan Kecamatan Wanea Kota Manado', 'Acta Diurna', IV(4).

Setiadi, E. M. (2013). Pengantar Sosiologi Pemahaman Fakta dan Gejala Permasalahan Sosial: Teori, Aplikasi dan Pemecahannya. Jakarta: Prenadamedia.

Sinaga, D. (1988). Sosiologi dan Antropologi. Palembang: PT. Intan Pariwara.
Soekanto, S. (2006). Sosiologi Suatu Pengantar. Jakarta: Raja Grapindo Persada.

Sugiana, D. (2016). 'Pola Jaringan Komunikasi Sosial Masyarakat Perdesaan Di Desa Sukaresik Kecamatan Sidamulih, Kabupaten Pangandaran', in.

Sugiyono (2013). Metode Penelitian Administrasi. Bandung: Alfabeta.

Sutrisno, H. (2001). Metode Research, Jilid I. Yogyakarta: Andi.

Thurlow, C. L. (2004). Computer Mediated Communication: Social Interaction and the Internet. New Delhi: SAGE Publications, Inc.

Triandis, H. (1980). Value Attitudes and Interpersonal Behavior. University of Nabraska: Press,Lincoln,NE.

West, L. T. (2010). Pengantar Teori Komunikasi: Analisis Dan Aplikasi. Jakarta: Salemba Humanika.

Yin, R. K. (2015). Studi Kasus: Desain dan Metode. Jakarta: Rajawali Pers. 